\title{
Waktu Dengung Ruang Sholat Masjid Desa Berdasarkan Perbedaan Bentuk Plafon
}

\author{
Elsa Fitria Bena, Beta Suryokusumo Sudarmo, Abraham M. Ridjal \\ Jurusan Arsitektur Fakultas Teknik Universitas Brawijaya \\ Alamat Email penulis: elsabenaa@gmail.com
}

\begin{abstract}
ABSTRAK
Ruang sholat masjid membutuhkan waktu dengung yang optimal agar kejelasan penyampaian suara di dalamnya baik. Dengan demikian kegiatan ibadah dapat berjalan dengan baik pula. Masjid desa diteliti karena keberadaannya dominan di Indonesia. Perbedaan bentuk geometrik ruang mempengaruhi kondisi akustik sehingga masjid desa dianalisis berdasarkan bentuk ruang berplafon kubah, tajug, dan datar. Penelitian akan dilakukan pada enam sampel ruang sholat masjid, masing-masing bentuk plafon diwakili dua sampel. Tidak ada dari keenam sampel yang menunjukkan RT hasil yang sesuai dengan standar. Keenam sampel memiliki RT yang lebih besar dari standar dan itu berarti keenam ruang sholat memiliki tingkat kejelasan penyampaian suara yang buruk. Hasil analisis menunjukkan bahwa ruang sholat masjid berplafon datar adalah yang paling baik daripada ruang sholat berplafon tajug dan kubah. Sedangkan yang paling buruk dari ketiganya adalah ruang sholat masjid berplafon kubah.
\end{abstract}

Kata kunci: waktu dengung, ruang sholat masjid, bentuk plafon

\begin{abstract}
Mosque's prayer hall needs optimal reverberation time to get clear sound in the mosque, especially during praying. Praying rites need clear sound. "Desa's" mosques are dominant in quantity in Indonesia. They had many different types. The difference of geometric form affected acoustic performance. In this study, Desa's mosques would be observed according to their space form: dome, tajug (crown), and flat ceiling. This study would observed six samples of prayer hall, with two samples for each type/form of ceiling: two samples for prayer hall with dome ceiling, two samples for prayer hall with crown ceiling, and two samples for prayer hall with flat ceiling. The result shows that there were no space-ceiling that have optimum reverberation time (RT). All space ceiling type have higher RT than the RT standart. It shows that all the samples perform bad quality of acoustic. According to this research, the best form of ceiling was flat ceiling, while dome ceiling was the worst ones.
\end{abstract}

Keywords: reverberation time, prayer hall of mosque, form of ceiling

\section{Pendahuluan}

Kegiatan dalam ruang sholat masjid yang sering dilakukan adalah kegiatankegiatan ibadah yang membutuhkan kejelasan penyampaian suara, seperti sholat berjamaah, pembacaan ayat suci, dan ceramah keagamaan. Kegiatan-kegiatan tersebut bisa dilakukan dengan baik jika sebuah masjid memiliki kualitas akustik yang baik. Kejelasan penyampaian suara ditentukan oleh parameter akustika ruang, yaitu waktu dengung (RT). Fungsi masjid masuk ke dalam fungsi ruang perbincangan (speech) yang membutuhkan waktu dengung cenderung pendek. 
Dewan Masjid Indonesia menjelaskan bahwa sekitar 70\% masjid memiliki nilai kualitas akustik yang buruk. Jenis masjid desa (masjid yang berkapasitas 100-400 orang) banyak tersebar di Indonesia sehingga jenis masjid ini perlu dikaji lebih lanjut.

Kualitas akustik ruang dipengaruhi oleh bentuk geometrik ruang itu sendiri. Setiyowati (2008) dan Setiawan (2011) sama-sama mengkaji akustik ruang masjid berdasarkan perbedaan bentuk plafon yang dibagi menjadi tiga bentuk, yaitu kubah, tajug, dan datar. Ketiga bentuk plafon masjid ini dianggap mewakili tipologi masjid yang berkembang di Indonesia, sehingga penelitian akan difokuskan pada ruang sholat masjid desa berdasarkan perbedaan bentuk plafon kubah, tajug, dan datar.

\section{Bahan dan Metode}

Metode penelitian adalah metode evaluasi dengan analisis kuantitatif dan kualitatif. Metode untuk mengevaluasi waktu dengung pada sampel-sampel ruang sholat masjid dilakukan dengan metode Sabine. Ada enam sampel yang akan dianalisis, yang terdiri dari dua buah sampel ruang sholat masjid desa berplafon kubah, dua buah sampel ruang sholat masjid desa berplafon tajug, dan dua buah sampel ruang sholat masjid desa berplafon datar. Nilai RT yang dianalisis adalah nilai RT pada frekuensi tengah $(500 \mathrm{~Hz})$.

\subsection{Akustik Ruang}

Bunyi (sound) adalah gelombang getaran mekanis di dalam udara atau benda padat yang masih bisa ditangkap oleh telinga manusia dengan rentan frekuensi antara 20-20.000 Hz (Satwiko, 2009). Bunyi merupakan transmisi energi yang melewati media padat, cair, dan gas dalam suatu getaran yang diterima melalui sensasi telinga dan otak (Mediastika, 2005).

Kecepatan bunyi (sound velocity) merupakan kecepatan rambat gelombang bunyi pada suatu media, dengan satuan meter/detik. Kecepatan bunyi tidak tergantung pada frekuensinya. Kecepatan rambat bunyi di udara adalah 340 meter/detik. Frekuensi bunyi (sound frequency) adalah jumlah getaran setiap detik dan dikur dengan satuan Hertz (Hz). Frekuensi menentukan tinggi rendahnya bunyi. Semakin tinggi frekuensi, semakin tinggi bunyi. Frekuensi standar yang dipilih sebagai wakil yang penting dalam arsitektur lingkungan adalah 125, 250, 500, 1000, 2000, dan 4000 $\mathrm{Hz}$ (Doelle \& Prasetio, 1993) . Sedangkan percakapan manusia berada pada 600-4000 Hz (Satwiko, 2009).

\subsubsection{Perilaku Bunyi di dalam Ruang}

Dalam perancangan objek arsitektur, seringkali perancang akan menemui permasalahan akustik yang berhubungan dengan ruang tertutup. Doelle (1993) menyebutkan beberapa gejala akustik pada ruang tertutup sebagai hasil dari pendekatan dengan akustik geometrik, yaitu pemantulan bunyi, penyerapan bunyi, difusi bunyi, difraksi bunyi, dengung, dan resonansi ruang. 


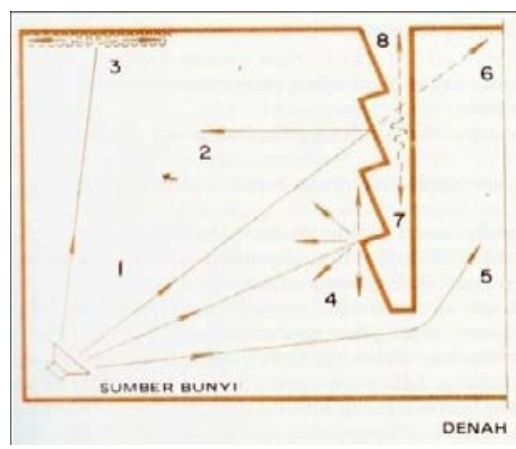

Gambar 1. Kelakuan bunyi dalam ruang tertutup: (1) bunyi datang atau bunyi langsung; (2) bunyi pantul; (3) bunyi yang diserap oleh lapisan permukaan; (4) bunyi difus atau bunyi yang disebar; (5) bunyi difraksi atau bunyi yang dibelokkan; (6) bunyi yang ditransmis (Sumber: Doelle, 1993)

Proses perambatan gelombang bunyi pada ruang tertutup tidak sama dengan ruang terbuka. Bidang-bidang pembatas ruangan seperti dinding, lantai, dan plafon, menyebabkan proses perambatan gelombang bunyi ke segala arah mengalami pembatasan. Bunyi yang merambat di dalam ruang akan mengalami berbagai peristiwa bergantung pada karakteristik bidang pembatas dan jenis frekuensi bunyi, seperti refleksi, difusi, absobsi, difraksi, dan refraksi (Mediastika, 2009: 61-71).

\subsubsection{Akustik dan Bentuk Geometrik Ruang}

Bentuk merupakan salah satu unsur yang turut mendukung pengkondisian akusik suatu ruang sebagai elemen nonstruktural, tapi bisa juga sebagai elemen struktural. Suptandar (2004) membagi bentuk geometris ruang berdasarkan kondisi akustik menjadi tiga, antara lain bentuk cekung, cembung, dan datar.

Bentuk cekung bersifat pemusatan suara yang tidak menyebar. Bentuk ini menimbulkan efek vokal point atau sebagai pusat arah pantulan suara dan memunculkan gema yang merambat. Permukaan cekung akan memantulkan cahaya terfokus ke titik yang sama. Pendengar di titik itu akan mendengar suara yang sangat keras dan yang jauh dari situ akan mendapat sedikit suara. Oleh karena itu bentuk ini adalah akustik yang buruk yang dapat menebabkan gema.

Bentuk cembung merupakan sebuah bentuk pemantul suara yang baik karena memiliki sifat penyebar gelombang suara yang mendukung kondisi difusi akustik ruang. Bentuk cembung ini bisa menciptakan kejelasan penyampaian suara dari berbagai arah yang cukup luas dan menyebar.

Bentuk akustik datar memiliki sifat yang paling sederhana dan jelas. Bentuk akustik datar akan memberikan suara yang jelas kepada penonton yang duduk di baris paling belakang tanpa cacat dan perbedaan tempo penerimaan.
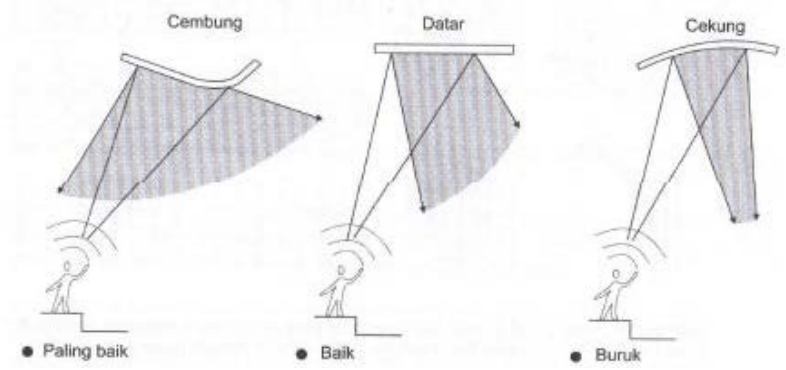

Gambar 2. Pemantulan yang Terjadi pada Bidang Batas

(Sumber: Mediastika, 2005) 


\subsubsection{Waktu Dengung}

Kualitas pemantulan dengung (reverberation) ditentukan oleh reverberation time atau waktu dengung. Waktu dengung (RT) merupakan waktu gelombang bunyi untuk melemah ketika sumber bunyi dihentikan. Perlemahan ini sangat bergantung pada kemampuan pantul bidang-bidang pembatas ruang, seperti lantai, dinding, dan plafon. Semakin keras dan licin permukaan pembatas, maka pelemahan bunyi semakin lambat (Mediastika, 2009: 101).

$$
\begin{aligned}
& \mathrm{RT}=0,16(\mathrm{~V} / \Sigma \mathrm{S} \alpha) \\
& \text { dengan: } \\
& \begin{array}{l}
\mathrm{RT} \quad \text { = waktu dengung (detik) } \\
\mathrm{V} \quad=\text { volume ruang }\left(\mathrm{m}^{3}\right) \\
\Sigma \mathrm{S} \alpha \quad=\text { penyerapan total (Sabine) }
\end{array}
\end{aligned}
$$

Nilai RT ideal suatu ruangan sangat bergantung pada fungsi ruang dan volume ruang secara utuh. Jenis ruang dibedakan menjadi dua, yaitu ruang yang dipergunakan untuk kegiatan bercakap-cakap (speech) dan ruang yang dipergunakan untuk kegiatan musik (Mediastika, 2009: 102). Aktivitas yang dilakukan di dalam masjid adalah aktivitas ibadah seperti sholat berjamaah, ceramah agama, dan pembacaan ayat suci. Keseluruh aktivitas tersebut dikategorikan sebagai aktivitas percakapan (speech) sehingga waktu dengung ideal untuk masjid adalah RT ideal untuk ruang percakapan.

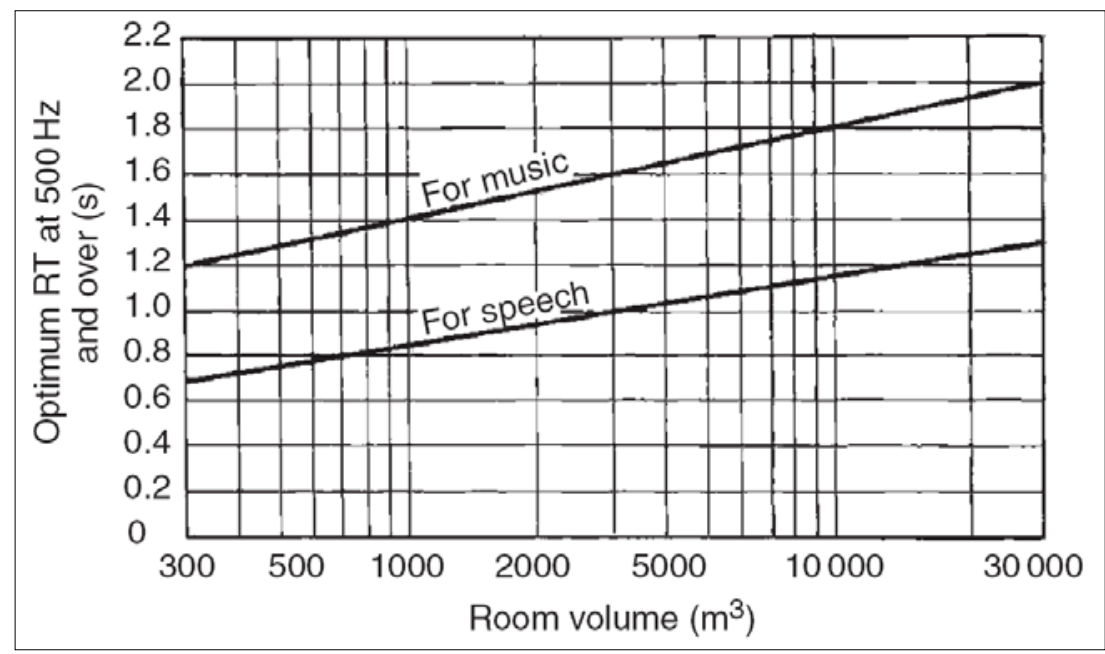

Gambar 3. Waktu Dengung yang direkomendasikan Berdasarkan Volume Ruang (Sumber: Szokolay, 2004: 181)

\subsection{Tinjauan Masjid}

Masjid adalah tempat sembahyang dari segi harfiah (Juliadi, 2007). Sedangkan Tugiyono KS (2001) menjelaskan beberapa pengertian tentang masjid. Masjid merupakan bangunan suci agama Islam dan merupakan tempat untuk melaksanakan ibadah bagi kaum muslimin dalam arti yang seluas-luasnya. Masjid adalah tempat untuk sujud dalam ibadah menurut pengertian yang seluas-luasnya, meliputi semua bidang kehidupan manusia. 
Terdapat unsur universal sebagai bentuk tampilan yang telah baku dan disepakati oleh umat sebagai sosok tampilan sebuah masjid (Fanani, 2009). Masjid ada untuk menampung keperluan ibadah shalat berjamaah. Dengan demikian, beberapa di antara unsur universal tadi perlu memenuhi tuntutan syarat rukun penyelenggara ibadah shalat berjamaah itu sendiri.

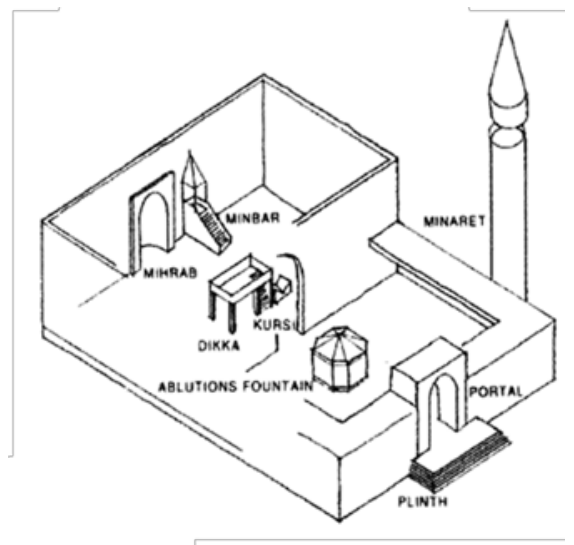

Gambar 4. Tampilan Baku Masjid

(Sumber: Fanani, 2009: 81)

Berdasarkan surat Direktorat Jendral Bimas Islam Direktorat Urusan Agama (dalam Massiki, 2011) tingkatan jenis masjid disusun berdasarkan kapasitasnya, yaitu sebagai berikut.

- Langgar atau mushola, yaitu tempat ibadah yang terletak di dalam atau lingkungan rumah tinggal (lingkup RT), maupun tempat-tempat publik seperti kantor dan pusat perbelanjaan. Masjid ini tidak digunakan untuk sholat Jumat.

- Masjid desa, yaitu masjid yang berada di lingkungan permukiman atau perumahan (RW). Batasan lingkup pelayanannya adalah dapat dipakai untuk sholat jum'at dan juga sholat Ied dengan kapasitas jamaah lebih dari 40 orang (100-400 orang)

- Masjid besar, yaitu masjid yang memiliki lingkup pelayanan di tingkat kecamatan. Masjid ini digunakan untuk sholat jum'at dan sholat Ied dengan kapasitas 10002000 jamaah

- Masjid raya, yaitu masjid yang merupakan masjid terbesar yang ada di suatu kota/kabupaten. Kapasitas jamaah lebih dari 2000 jamaah.

- Masjid agung, masjid yang merupakan masjid terbesar di suatu propinsi. Kapasitas jamaah lebih dari 2000 jamaah

- Masjid Negara, yaitu masjid terbesar yang ada di suatu negara.

Susanta, Amin, \& Kautsar (2007: 21) menyebutkan bahwa dalam masjid terdapat ruang-ruang inti yang merupakan ruang utama pada sebuah masjid, yaitu ruang sholat, ruang untuk bersuci, dan beranda. Terlepas dari ukuran luas dan kategori masjid yang bersangkutan, sebah masjid diharuskan memiliki ruang-ruang inti tersebut. Ruang sholat merupakan ruang utama pada masjid yang terdiri dari mihrab dan ruang jemaah. Ruang bersuci (wudhu) merupakan tempat yang tidak terpisahkan dari keberadaan suatu masjid. Teras atau beranda berfungsi untuk menjaga kebersihan dan kesucian ruang sholat.

Dari ketiga ruangan inti tersebut, ruang yang membutuhkan adanya kenyamanan mendengar adalah ruang sholat karena berkaitan dengan kegiatan di dalamnya yang digunakan untuk sholat berjamaah dan mendengarkan ceramah agama. Maka, ruang inti yang akan dijadikan fokus pada kajian akustika masjid ini adalah ruang sholat. 
3. Hasil dan Pembahasan

3.1 Ruang Sholat Masjid Desa Berplafon Kubah

3.1.1 Masjid Nur Inka Kota Malang

Masjid Nur Inka memiliki kapasitas 150 jamaah dengan bentuk denah didominasi bentukan persegi. Plafon ruangan adalah kubah. Volume ruang adalah $1323,88 \mathrm{~m}^{3}$.
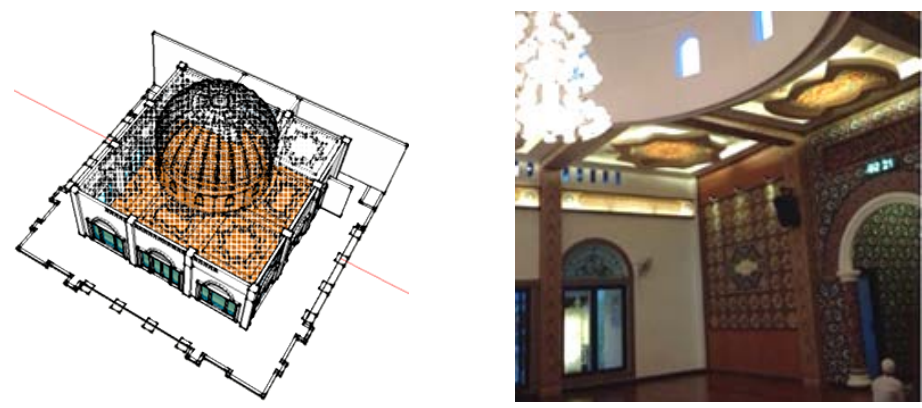

Gambar 5. Tampilan Ruang Sholat Masjid Nur Inka (Sumber: Hasil analisis, 2014)

Tabel 1. Data Material Ruang Sholat Masjid Nur Inka

\begin{tabular}{lrccc}
\hline Material & Luas $\left(\mathbf{m}^{\mathbf{}} \mathbf{)}\right.$ & \multicolumn{1}{c}{ \% } & Koefisien Serap & Keterangan \\
\hline Bata dicat & 81,06 & 12,90 & 0,02 & Pemantul suara \\
Beton plester & 5,91 & 0,94 & 0,01 & Pemantul suara \\
Kaca buram & 7,63 & 1,21 & 0,04 & Pemantul suara \\
Kaca & 30,53 & 4,86 & 0,18 & Penyerap suara \\
Kayu lantai & 118,35 & 18,83 & 0,07 & Pemantul suara \\
Kayu & 28,7 & 4,57 & 0,10 & Pemantul suara \\
Aluminium & 26,59 & 4,23 & 0,07 & Pemantul suara \\
Bukaan & 2,56 & 0,41 & 1,00 & Penyerap suara \\
Wallpaper & 109,93 & 17,49 & 0,02 & Pemantul suara \\
Gypsum & 156,32 & 24,87 & 0,05 & Pemantul suara \\
Kaca lampu & 60,92 & 9,69 & 0,03 & Pemantul suara \\
\hline Total & 628,59 & 100 & - & \\
\hline
\end{tabular}

(Sumber: Hasil analisis, 2014)

Tabel 2. RT Hasil Ruang Sholat Masjid Nur Inka

\begin{tabular}{lccl}
\hline \multicolumn{1}{c}{ Kondisi } & $\begin{array}{c}\text { RT hasil } \\
\text { (detik) }\end{array}$ & $\begin{array}{c}\text { RT standar } \\
\text { (detik) }\end{array}$ & Keterangan \\
\hline Kondisi kosong jamaah & 6,07 & 1,10 & Melebihi standar \\
Kondisi 2/3 penuh & 2,68 & 0,85 & Melebihi standar \\
Kondisi penuh jamaah & 2,10 & 0,70 & Melebihi standar \\
\hline
\end{tabular}

(Sumber: Hasil analisis, 2014)

Hasil analisis Sabine menunjukkan hasil RT $500 \mathrm{~Hz}$ ruang sholat Masjid Nur Inka lebih besar daripada nilai standar. Hal ini menunjukkan bahwa terjadi dengung yang panjang pada ruang sholat Masjid Nur Inka sehingga kejelasan pembicaraan di dalamnya sangat buruk. Permasalahan utama ruang sholat ini adalah karena terlalu banyak menggunakan material yang bersifat memantulkan suara $(94,73 \%)$

\subsubsection{Masjid Abdillah Kota Malang}

Kapasitas jamaah ruang sholat Masjid Abdillah adalah 128 orang dengan volume sebesar 955,11 $\mathrm{m}^{2}$. Bentuk denah ruang dominan persegi dengan bentuk plafon berbentuk kubah. 

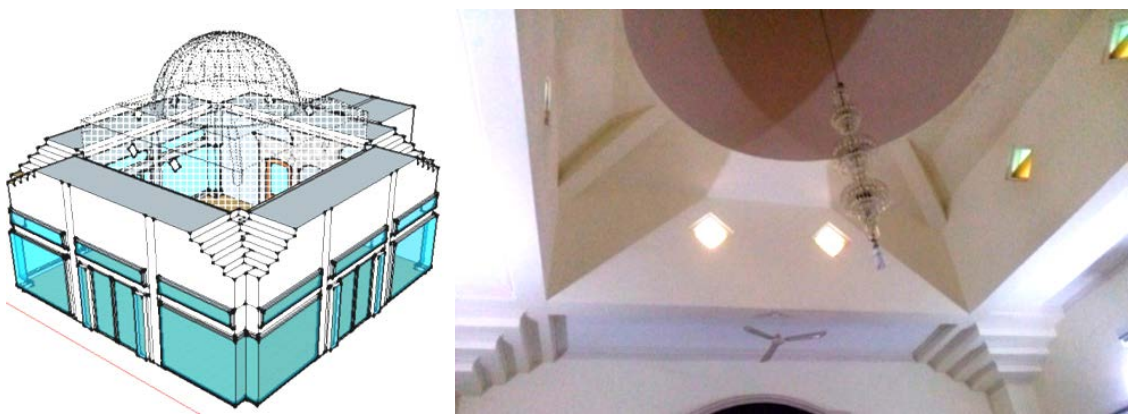

Gambar 6. Tampilan Ruang Sholat Masjid Abdillah

(Sumber: Hasil analisis, 2014)

Tabel 3. Data Material Ruang Sholat Masjid Abdillah

\begin{tabular}{lcccc}
\hline Material & Luas permukaan $\left(\mathbf{m}^{\mathbf{2}}\right)$ & $\mathbf{\%}$ & Koefisien serap & Keterangan \\
\hline Bata dicat & 64,9 & 14,08 & 0,02 & Pemantul suara \\
Beton dicat & 138 & 29,89 & 0,01 & Pemantul suara \\
Kaca buram & 0,64 & 0,14 & 0,04 & Pemantul suara \\
Kaca & 58,38 & 12,66 & 0,18 & Penyerap suara \\
Kayu & 4,57 & 0,99 & 0,1 & Pemantul suara \\
Gypsum & 44,82 & 9,72 & 0,05 & Pemantul suara \\
Keramik & 22,88 & 4,96 & 0,01 & Pemantul suara \\
Marmer & 11,8 & 2,56 & 0,01 & Pemantul suara \\
Karpet & 98,04 & 21,27 & 0,14 & Penyerap suara \\
Aluminium & 17,17 & 3,72 & 0,07 & Pemantul suara \\
\hline Total & 461,2 & 100 & - & \\
\hline
\end{tabular}

(Sumber: Hasil analisis, 2014)

Tabel 4. RT Hasil Ruang Sholat Masjid Abdillah

\begin{tabular}{lccl}
\hline \multicolumn{1}{c}{ Kondisi } & $\begin{array}{c}\text { RT hasil } \\
\text { (detik) }\end{array}$ & RT standar (detik) & Keterangan \\
\hline Kondisi kosong jamaah & 4,64 & 1,10 & Melebihi standar \\
Kondisi 2/3 penuh & 2,17 & 0,85 & Melebihi standar \\
Kondisi penuh jamaah & 1,71 & 0,70 & Melebihi standar \\
\hline
\end{tabular}

(Sumber: Hasil analisis, 2014)

Hasil perhitungan menunjukkan RT hasil yang melebihi nilai standar pada setiap kondisi jamaah, sehingga dapat dikatakan bahwa teradapat dengung yang besar di dalam ruangan. Permasalahan utama ruang sholat Masjid Abdillah adalah pada pemakaian material pemantul suara yang lebih dominan $(66,07 \%)$

\subsection{Ruang Sholat Masjid Desa Berplafon Tajug}

\subsubsection{Masjid Al Hikmah Kota Malang}

Kapasitas jamaah ruang sholat Masjid Al Hikmah adalah 200 orang dengan volume sebesar $1269,81 \mathrm{~m}^{3}$. 

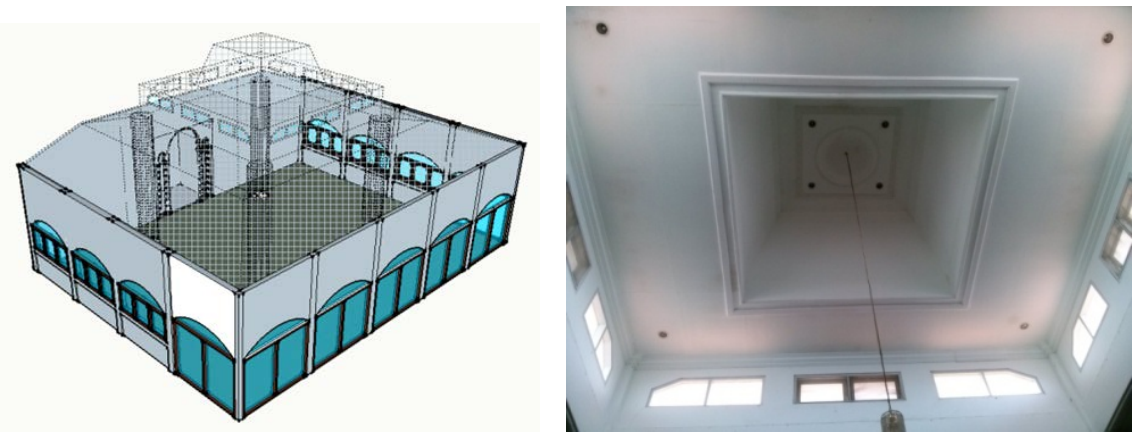

Gambar 7. Tampilan Ruang Sholat Masjid Al Hikmah

(Sumber: Hasil analisis, 2014)

Tabel 5. Data Material Ruang Sholat Masjid Al Hikmah

\begin{tabular}{lcccc}
\hline \multicolumn{1}{c}{ Material } & $\begin{array}{c}\text { Luas permukaan } \\
\left(\mathbf{m}^{\mathbf{2}} \mathbf{c}\right.\end{array}$ & $\mathbf{\%}$ & $\begin{array}{c}\text { Koefisien } \\
\text { serap }\end{array}$ & Keterangan \\
\hline Bata (plester + cat) & 30,81 & 4,21 & 0,02 & Pemantul suara \\
Kaca & 62 & 8,47 & 0,18 & Penyerap suara \\
Kayu & 5,75 & 0,79 & 0,1 & Pemantul suara \\
Aluminium & 27,55 & 3,76 & 0,07 & Pemantul suara \\
Eternit & 183,44 & 25,06 & 0,18 & Penyerap suara \\
Keramik & 164,02 & 22,41 & 0,01 & Pemantul suara \\
Karpet & 191,76 & 26,20 & 0,14 & Penyerap suara \\
Marmer & 66,68 & 9,11 & 0,01 & Pemantul suara \\
\hline Total luas permukaan & 732,01 & 100 & & \\
\hline
\end{tabular}

(Sumber: Hasil analisis, 2014)

Tabel 6. RT Hasil Ruang Sholat Masjid Al Hikmah

\begin{tabular}{lccl}
\hline \multicolumn{1}{c}{ Kondisi } & $\begin{array}{c}\text { RT hasil } \\
\text { (detik) }\end{array}$ & RT standar (detik) & Keterangan \\
\hline Kondisi kosong jamaah & 2,66 & 1,20 & Melebihi standar \\
Kondisi 2/3 penuh & 1,51 & 0,90 & Melebihi standar \\
Kondisi penuh jamaah & 1,24 & 0,75 & Melebihi standar \\
\hline
\end{tabular}

(Sumber: Hasil analisis, 2014)

Ruang sholat Masjid Al Hikmah yang berplafon tajug memiliki nilai RT yang melebihi standar di setiap kondisi jamaah. Terdapat dengung yang panjang sehingga dapat dipastikan bahwa tingkat kejelasan pembicaraan di dalam ruang buruk. Permasalahan utama pada ruang sholat ini adalah pada pemakaian material yang memiliki koefisien serap kecil.

\subsubsection{Masjid Ar Ridlo Kota Malang}

Masjid Ar Ridlo memiliki kapasitas jamaah sebesar 400 orang dengan volume ruang $2414,42 \mathrm{~m}^{3}$. Bentuk denah dari ruang sholat ini dominan persegi.

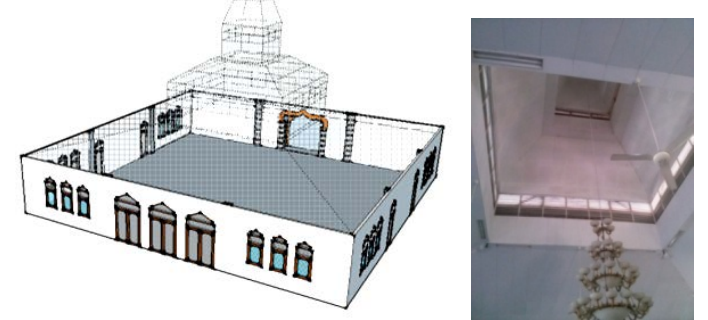

Gambar 8. Tampilan Ruang Sholat Masjid Ar Ridlo

(Sumber: Hasil analisis, 2014) 
Tabel 7. Data Material Ruang Sholat Masjid Ar Ridlo

\begin{tabular}{lcrcl}
\hline Material & $\begin{array}{c}\text { Luas permukaan } \\
\left(\mathrm{m}^{2}\right)\end{array}$ & $\begin{array}{l}\text { Koefisien } \\
\text { serap }\end{array}$ & Keterangan \\
\hline Bata (plester + cat) & 154,21 & 10,72 & 0,02 & Pemantul suara \\
Kaca & 9,81 & 0,68 & 0,18 & Penyerap suara \\
Open windows & 49,52 & 3,44 & 1,00 & Penyerap suara \\
Kayu & 75,29 & 5,24 & 0,10 & Pemantul suara \\
Eternit & 541,35 & 37,65 & 0,18 & Penyerap suara \\
Keramik & 149,81 & 10,42 & 0,01 & Pemantul suara \\
Karpet & 438,09 & 30,47 & 0,14 & Penyerap suara \\
Marmer & 11,05 & 0,77 & 0,01 & Pemantul suara \\
Beton plester & 8,82 & 0,61 & 0,01 & Pemantul suara \\
\hline Total luas permukaan & 1437,95 & 100 & & \\
\hline
\end{tabular}

(Sumber: Hasil analisis, 2014)

Tabel 8. RT Hasil Ruang Sholat Masjid Ar Ridlo

\begin{tabular}{cccc}
\hline Kondisi & $\begin{array}{c}\text { RT hasil } \\
\text { (detik) }\end{array}$ & $\begin{array}{c}\text { RT standar } \\
\text { (detik) }\end{array}$ & Keterangan \\
\hline Kosong jamaah & 1,74 & 1,74 & Melebihi standar \\
2/3 jamaah & 1,03 & 0,95 & Berada pada rentan yang direkomendasikan \\
Penuh jamaah & 0,86 & 0,85 & Berada pada rentan yang direkomendasikan \\
\hline
\end{tabular}

(Sumber: Hasil analisis, 2014)

Ruang sholat Masjid A Ridlo memiliki nilai RT yang melebihi standar pada kondisi kosong jamaah. Terdapat dengung yang panjang sehingga tingkat kejelasan pembicaraan di dalam ruang buruk. Permasalahan utama pada ruang sholat ini adalah pada pemakaian material yang memiliki koefisien serap kecil.

\subsection{Ruang Sholat Masjid Desa Berplafon Datar}

\subsubsection{Masjid Nurut Taqwa Kota Malang}

Kapasitas total ruang sholat Masjid Nurut Taqwa adalah 128 orang. Volume total ruang sholat ini ada;ah 536,07 $\mathrm{m}^{3}$. Bentuk denahnya persegi panjang.
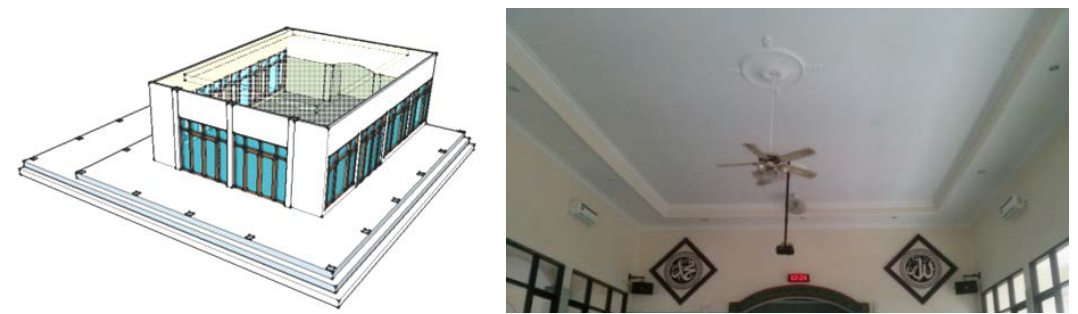

Gambar 9. Tampilan Ruang Sholat Masjid Nurut Taqwa

(Sumber: Hasil analisis, 2014)

Tabel 9. Data Material Ruang Sholat Masjid Nurut Taqwa

\begin{tabular}{lccll}
\hline Material & $\begin{array}{l}\text { Luas permukaan } \\
\left(\mathbf{m}^{\mathbf{2}} \mathbf{)}\right.\end{array}$ & $\mathbf{\%}$ & $\begin{array}{l}\text { Koefisien } \\
\text { serap }\end{array}$ & Keterangan \\
\hline Bata (plester + cat) & 59,19 & 14,03 & 0,02 & Pemantul suara \\
Beton plester & 6,20 & 1,47 & 0,01 & Pemantul suara \\
Kaca & 50,76 & 12,03 & 0,18 & Penyerap suara \\
Aluminium & 29,9 & 7,08 & 0,07 & Pemantul suara \\
Eternit & 115,85 & 27,45 & 0,18 & Penyerap suara \\
Keramik & 50,13 & 11,88 & 0,01 & Pemantul suara \\
Karpet & 110 & 26,06 & 0,14 & Penyerap suara \\
\hline Total & 422,03 & 100 & & \\
\hline
\end{tabular}

(Sumber: Hasil analisis, 2014) 
Tabel 10. RT Hasil Ruang Sholat Masjid Nurut Taqwa

\begin{tabular}{cccc}
\hline Kondisi & $\begin{array}{c}\text { RT hasil } \\
\text { (detik) }\end{array}$ & $\begin{array}{c}\text { RT standar } \\
\text { (detik) }\end{array}$ & Keterangan \\
\hline Kosong jamaah & 1,80 & 1,00 & Melebihi standar \\
2/3 jamaah & 1,01 & 0,75 & Melebihi standar \\
Penuh jamaah & 0,82 & 0,60 & Berada pada rentan yang dipersyaratkan \\
\hline (Sumber: Hasil analisis, 2014) & &
\end{tabular}

Waktu dengung masjid Nurut Taqwa melebihi nilai standar pada kondisi kosong jamaah dan terisi sebagian jamaah. Sedangkan pada kondisi penuh jamaah, waktu dengung ruang ini berada pada rentan nilai standar. Permasalahan waktu dengung pada ruang sholat ini adalah pada penggunaan material yang memiliki koefisien serap rendah.

\subsubsection{Masjid Baithul Ghoni Kota Malang}

Masjid Baithul Ghoni memiliki plafon dengan bentuk datar. Kapasitas jamaah di dalam ruangnya adalah 128 orang dengan volume ruang sebesar 599,76 m³.
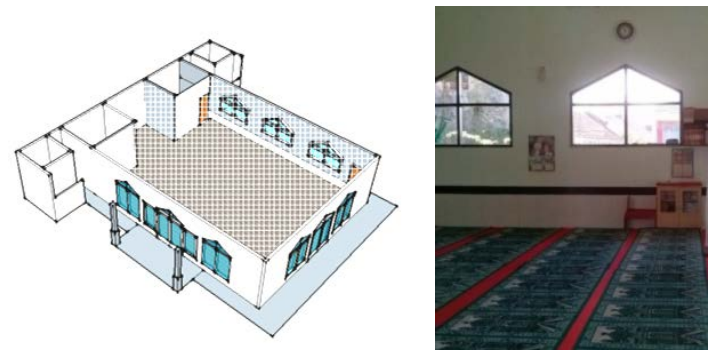

Gambar 10. Tampilan Ruang Sholat Masjid Baithul Ghoni (Sumber: Hasil analisis, 2014)

Tabel 11. Data Material Ruang Sholat Masjid Baithul Ghoni

\begin{tabular}{lcccl}
\hline Material & $\begin{array}{c}\text { Luas permukaan } \\
\left(\mathbf{m}^{\mathbf{2}} \mathbf{)}\right.\end{array}$ & $\mathbf{\%}$ & $\begin{array}{c}\text { Koefisien } \\
\text { serap }\end{array}$ & Keterangan \\
\hline Bata dicat & 144,98 & 30,29 & 0,02 & Pemantul suara \\
Kaca & 25,32 & 5,29 & 0,18 & Penyerap suara \\
Kayu & 30,95 & 6,47 & 0,10 & Pemantul suara \\
Eternit & 126,29 & 26,38 & 0,18 & Penyerap suara \\
Keramik & 24,88 & 5,20 & 0,01 & Pemantul suara \\
Karpet & 126,29 & 26,38 & 0,14 & Penyerap suara \\
\hline Total luas permukaan & $\mathbf{4 7 8 , 7 1}$ & 100 & & \\
\hline \multicolumn{4}{l}{ (Sumber: Hasil analisis, 2014) }
\end{tabular}

Tabel 12. RT Hasil Ruang Sholat Masjid Baithul Ghoni

\begin{tabular}{cccc}
\hline Kondisi & $\begin{array}{c}\text { RT } \\
\text { hasil } \\
\text { (detik) }\end{array}$ & $\begin{array}{c}\text { RT } \\
\text { standar } \\
\text { (detik) }\end{array}$ & Keterangan \\
\hline Kosong jamaah & 1,87 & 1,00 & Melebihi standar \\
2/3 jamaah & 1,08 & 0,75 & Melebihi standar \\
Penuh jamaah & 0,89 & 0,60 & Berada pada rentan standar yang direkomendasikan \\
\hline
\end{tabular}

(Sumber: Hasil analisis, 2014)

Sama halnya dengan Masjid Nurut Taqwa, ruang sholat Masjid Baithul Ghoni memiliki waktu dengung yang melebihi standar pada kondisi kosong dan terisi sebagian jamaah, sedangkan waktu dengung pada kondisi penuh jamaah adalah berada pada 
rentan standar. Permasalahan pada ruang sholat Baithul Ghoni adalah pada pemakaian material yang berkoefisien serap kecil.

\subsection{Perbandingan Ruang Sholat Masjid Berdasarkan Perbedaan Bentuk Plafon}

Keseluruhan ruang sholat masjid yang dianalisis menunjukkan kecenderungan yang sama, yaitu RT maksimal berada pada kondisi ruangan kosong jamaah dan RT minimal berada pada kondisi ruangan penuh dengan jamaah. Hal ini terjadi karena manusia memiliki koefisien serap yang memengaruhi penyerapan bunyi di dalam ruang. Jumlah manusia yang banyak membuat bunyi lebih terserap sehingga dengung di dalam ruang menjadi lebih kecil jika dibandingkan dengan kondisi ruangan kosong. Jumlah jamaah berbanding terbalik dengan RT ruangan.

Hasil analisis juga menunjukkan bahwa tidak ada dari keenam objek kajian yang memiliki kualitas akustik yang sesuai dengan standar yang dipersyaratkan. Keseluruhan ruang sholat masjid yang telah dianalisis, baik yang berplafon kubah, tajug, dan datar memiliki RT yang melebihi standar. Ini menunjukkan bahwa terjadi dengung yang berlebihan pada keenam ruang sholat tersebut.
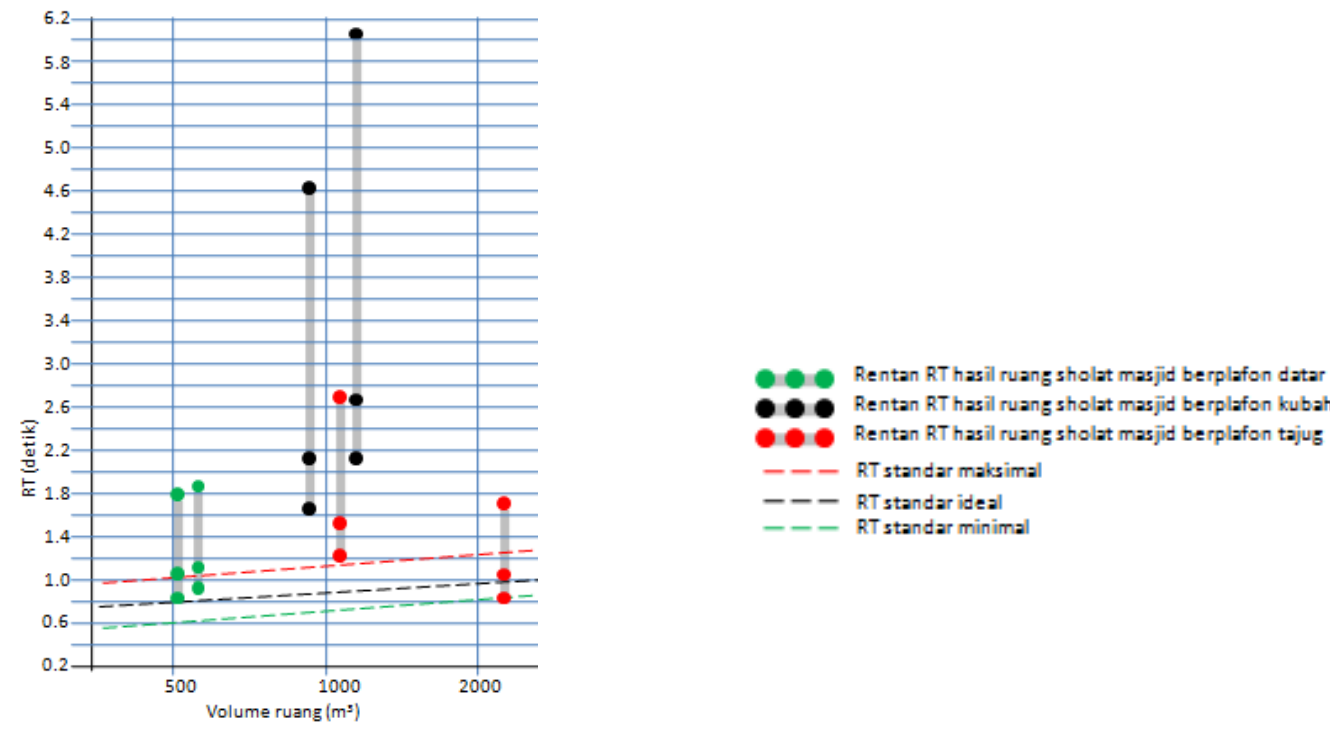

Gambar 11. Grafik Perbandingan RT Hasil Keenam Sampel Ruang Sholat (Sumber: Hasil analisis, 2014)

Jika ketiga model ruang sholat masjid ini dibandingkan, dapat dilihat bahwa nilai RT ruang sholat masjid berplafon datar menunjukkan hasil yang lebih kecil dan lebih mendekati nilai standar daripada ruang sholat masjid yang berplafon kubah dan tajug. Ini menunjukkan bahwa ruang sholat masjid berplafon datar memiliki kondisi akustik yang lebih baik daripada ruang sholat masjid berplafon kubah dan tajug. Dengan demikian tingkat kejelasan pembicaraan di dalam ruang sholat berplafon datar akan lebih tinggi dan lebih jernih daripada ruang sholat masjid berplafon kubah atau tajug.

Sedangkan ruang sholat masjid yang paling buruk dari aspek RT adalah ruang sholat masjid yang berplafon kubah karena RT pada ruang sholat masjid yang berplafon kubah cenderung paling jauh dari standar yang direkomendasikan. Ini menunjukkan bahwa tingkat kejelasan pembicaraan pada ruang sholat masjid yang berplafon kubah adalah yang paling buruk akibat dengung di dalam ruang yang tinggi.

Hal ini terjadi karena bentuk kubah yang cekung membuat bunyi di dalam ruang terpantul pada satu titik sehingga timbul dengung yang lebih panjang. Selain itu bunyi 
akan merambat pada bidang lengkungan kubah yang berbentuk cekung sehingga menyebabkan suara tidak dapat tersebar rata. Persebaran bunyi pada ruang sholat dengan plafon kubah menjadi kurang baik untuk ruang dengan fungsi speech.

Sedangkan bentuk ruang sholat berplafon tajug juga memiliki kecenderungan yang sama dengan ruang sholat masjid berplafon kubah, yaitu memiliki nilai RT di atas standar yang direkomendasikan. Namun RT ruang sholat masjid berplafon tajug bisa dikatakan lebih baik daripada ruang sholat berplafon kubah karena lebih mendekati standar yang direkomendasikan.

Pada dasarnya bentuk plafon tajug merupakan bentuk modifikasi dari bentuk datar sehingga pemantulan bunyi pada ruang sholat berplafon tajug lebih sederhana jika dibandingkan dengan bentuk kubah. Hal ini yang membuat RT ruang sholat masjid berplafon tajug lebih baik daripada masjid berplafon kubah. Hanya saja pada bentuk plafon tajug, terdapat bentuk datar yang memiliki sudut kemiringan dan saling berhadapan. Kondisi ini membuat bunyi menjadi terpantul berkali-kali terlebih dahulu sebelum kemudian hilang. Akibatnya, terjadi dengung di dalam ruangan.

Sementara itu bentuk plafon datar memiliki bentuk yang paling sederhana dari bentuk lainnya sehingga pemantulan suara pada ruang lebih merata. Tidak ada suara yang terpantul berkali-kali seperti pada bentuk tajug. Tidak ada suara yang terkumpul pada satu titik seperti pada bentuk kubah. Suara cenderung tersebar dengan baik sehingga tidak terdapat dengung berlebihan yang mengganggu tingkat kejelasan suara. Hal ini yang menyebabkan nilai RT pada ruang sholat masjid berplafon datar paling baik dari bentuk yang lain.

\section{Kesimpulan}

- Waktu dengung sebuah ruang sholat selalu berubah-ubah, tergantung pada jumlah jamaah yang terdapat dalam ruang. Waktu dengung berbanding terbalik dengan jumlah jamaah. Waktu dengung maksimal ruang sholat terjadi saat ruangan kosong dengan jamaah, sedangkan waktu dengung minimal terjadi ketika ruangan penuh dengan jamaah.

- Tidak ada dari keenam ruang sholat masjid yang memiliki waktu dengung yang sesuai dengan standar yang direkomendasikan. Keseluruhan ruang sholat masjid, baik yang berplafon kubah, tajug, maupun datar memiliki RT yang melebihi nilai RT standar.

- Ruang sholat masjid berplafon datar lebih baik daripada ruang sholat berplafon kubah dan tajug karena memiliki nilai RT yang paling rendah. Sedangkan ruang sholat masjid yang paling buruk adalah model ruang sholat masjid berplafon kubah karena kecenderungan dengung di dalamnya paling tinggi.

- Permasalahan waktu dengung pada ruang sholat masjid desa, baik yang berplafon kubah, tajug, maupun datar adalah pada ketidaktepatan komposisi penggunaan material pemantul dan penyerap suara di dalam ruang, sehingga kualitas pemantulan di dalam ruang buruk dan menyebabkan dengung yang panjang.

\section{Daftar Pustaka}

Abdou, A. A. 2003. Measurement of Acoustical Characteristics of Mosques in Saudi Arabia. The Journal of the Acoustical Society of America. 113 (3): 1505-1517. (diakses 19 Maret 2014). 
Agustina, A. 2013. Indonesia Masih Membutuhkan 451.190 Masjid. http://m.inilah.com/read/detail/2015513/indonesia-masih-membutuhkan451190-masjid. (diakses 20 September 2013).

Doelle, L. L. \& Prasetio, L. 1993. Akustik Lingkungan. Jakarta: Erlangga.

Eldien, H. \& Qahtani, A. 2012. The Acoustical Performance of Mosques' Main Prayer Hall Geometry in the Eastern Province, Saudi Arabia. Proceedings of the Acoustics 2012 Nantes Conference: 949-955. Nantes: Acoustics 2012. (diakses 19 Maret 2014).

Fanani, A. 2009. Arsitektur Masjid. Yogyakarta: Bentang.

Heuken SJ, A. 2003. Mesjid-mesjid Tua di Jakarta. Jakarta: Yayasan Cipta Loka Caraka. Juliadi. 2007. Masjid Agung Banten: Nafas Sejarah dan Budaya. Yogyakarta: Ombak. Lord, P \& Templeton, D. 2001. Detail Akustik. Jakarta: Erlangga.

Mariani \& Rauf, N. 2008. Deskripsi Kondisi Akustik Ruang Masjid Al Markaz Al Islami Makassar. Jurnal SMARTek.6 (4): 246-260. (diakses 30 September 2013).

Massikki, M. N. 2011. Desain Akustik Ruang Sholat Masjid Agung Darussalam Palu. Jurnal Ruang. 2 (1): 14-27. (diakses 20 September 2013)

Mediastika, C. E. 2005. Akustika Bangunan Prinsip-prinsip dan Penerapannya di Indonesia. Jakarta: Erlangga.

Mediastika, C. E. 2009. Material Akustik Pengendali Kualitas Bunyi pada Bangunan. Yogyakarta: Andi.

Priliawito, E. \& Budiawati, A. D. 2014. JK: 70 Persen Masjid di Indonesia Kualitas Sound Systemnya Buruk. http://nasional.news.viva.co.id/news/read/476293-jk--70persen-masjid-di-indonesia-kualitas-sound-systemnya-buruk. (diakses 30 Maret 2014).

Riduwan. 2006. Belajar Mudah Penelitian untuk Guru-Karyawan dan Peneliti Pemula. Bandung: Alfabeta.

Satwiko, P. 2009. Fisika Bangunan. Yogyakarta: Penerbit Andi.

Setiawan. C. B., Rahmadiansah, A. \& Sawitri, D. 2011. Studi Kualitas Akustik Berdasarkan Waktu Dengung dan Bising Latar Belakang Masjid-Masjid Besar di Surabaya. Jurusan Teknik Fisika Institut Teknologi Sepuluh Nopember. 1-13. (diakses 30 September 2013).

Setiyowati, E. \& Nastiti N. E., S. 2008b. Nilai Akustik Ruang pada Masjid-Masjid di Daerah Permukiman dengan Bentuk Plafon yang Berbeda. Jurnal Rekayasa Perancangan. 4 (2). (diakses 20 September 2013).

Setiyowati, E. 2008a. Pengaruh Bentuk Arsitektur Masjid terhadap Kualitas Akustik Ruang. $\quad$ http://ninkarch.files.wordpress.com/2008/11/04/masjid-dan-akustik/ (diakses 30 September 2013).

Sugiyono. 2005. Statistika untuk Penelitian. Bandung: CV Alfabeta.

Suptandar, P. J. 2004. Faktor Akustik dalam Perancangan Desain Interior. Jakarta: Djambatan.

Suryono. 2012. Kajian Akustik Masjid Akhmad Yani Manado. Jurnal Sabua. 4 (1): 48-58. (diakses 7 Oktober 2013).

Susanta, G., Amin, C. \& Kautsar, R. 2007. Membangun Masjid dan Mushola. Jakarta: Penebar Swadaya.

Szokolay, S. V. 2004. Introduction to Architectural Science: The Basis of Sustainable Design. Burlington: Architectural Press.

Tugiyono KS, dkk. 2001. Peninggalan Situs dan Bangunan Bercorak Islam di Indonesia. Jakarta: RT Mutiara Sumber Widya. 